\title{
A GEOGRAPHIC ANALYSIS OF POST-DISASTER SOCIAL IMPACTS ON A MUNICIPAL SCALE - A CASE STUDY OF A POTENTIAL MAJOR FLOOD IN THE PARIS REGION (FRANCE)
}

\author{
Kenji FUJIKI, Florent RENARD
}

DOI: $10.21163 / G T \_2018.132 .03$

\begin{abstract}
:
In this study, a GIS methodology is developed to analyse post-disaster social impacts at the scale of municipalities. Two methods are combined here: (1) a model measuring flood damages to the structures and services necessary to populations' liveability. (2) A spatialized index, combining social variables in order to represent the recovery capability of populations. Municipalities combining a high damage ratio and a lack of recovery capability shall be closely watched during the planning process of post-disaster recovery. This study is original for methodological and conceptual reasons. The methodology combines tools which are rarely used together, whereas post-disaster impacts of the Seine flood, our case study, have not yet been fully analysed.
\end{abstract}

Key-words: Vulnerability, Post-disaster, Recovery, Flood, Paris region

\section{INTRODUCTION}

The flood of the Seine river is nowadays an issue well documented amongst crisis managers (November \& Créton-Cazanave, 2017). The June 2016 floods, which triggered the evacuation of almost 20,000 people inside the Paris region (called "Ile-de-France"3), and the more recent January 2018 floods, have highlighted the efforts in crisis management planning that have been made, though many difficulties and challenges persist. Conversely, post-disaster management remains a poorly known and controlled topic.

This deficiency in anticipation is to be related with the lack of feedbacks concerning plain flooding lasting several weeks or months in a highly urbanized community (MassonPlanchon \& Reghezza-Zitt, 2017). Indeed, the peculiarity of the Seine flood hazard is its slow onset, due to the slope of the watershed $(0.01 \%$ to $0.03 \%)$, and other diverse factors, such as the time transfer between the upstream and the Paris region (between 4 and 11 days). During the one-hundred-year flood of January 1910, water levels rose on average $1 \mathrm{~m}$ a day, while it took two months for the waters to recede (OECD, 2014). Anticipating postdisaster challenges is essential, due to the exposure of the Paris region to flood hazard 830,000 inhabitants are indeed exposed to a one-hundred-year flood (Faytre, 2011)

\subsection{Research topic and definitions: a major flood in the Paris region}

To face this lack of knowledge, the topic of this paper is to develop a methodology to study post-disaster social impacts, applied to a flood of the Seine river and its tributaries, equal or superior in flow to the 1910 flood, in the Paris region. This methodology aims at quantifying and mapping those impacts at the scale of the municipalities of the region.

\footnotetext{
${ }^{1}$ Strasbourg University, CNRS UMR 7362 LIVE, F-67000 Strasbourg. France. kenji.fujiki@livecnrs.unistra.fr

${ }^{2}$ Lyon 3 University, CNRS UMR 5600 EVS - CRGA, 69362 Lyon Cedex 07. France. florent.renard@univ-lyon3.fr

${ }^{3}$ In French, this name literally means: "Island of France".
} 


\subsubsection{Between physical and social impacts}

A flood may be defined as the temporary covering by water of land not usually covered by water (Torterotot, 1993). It may have different origins (Chocat, 1997) and it may cause various impacts, which may be classified according to a simple typology, between physical and social impacts (Lindell, 2013). Physical impacts include the effects of floods on people's health, but also the damages to buildings and infrastructures, the natural environment, and agricultural lands (Ahern et al., 2005; Brémond et al., 2013; Torterotot, 1993). Social impacts include effects on a psychological level, on the demographic and economic structure of the community, or on a political level (Aldrich, 2012; Baade et al., 2007; Bolin \& Stanford, 1991; Leon, 2004; Vigdor, 2008). If this paper is mainly focused on social impacts, it is nonetheless critical to also consider physical impacts in this analysis, as they are both deeply entangled. Decease has psychological effects, and damages to buildings hinder the return of evacuated and affected populations. On the other hand, the return of the latter also affects building and infrastructure reconstruction speed and rate (Green et al., 2007; Paxson \& Rouse, 2008). As this distinction appears misleading to a certain extent, social impacts have been defined more generally, as the effects of the flood on populations.

\subsubsection{Different approaches to recovery processes}

Impacts may be measured according to their timing, from short-term impacts caused by the immediate consequences of the flood (flooding of living places leading to evacuations, utilities and public services shutdowns, interruption of economic activity) to long-term impacts - how the flood has disturbed, for several years or more, the demographic and social fabric of a given community (Aldrich, 2012). These long-term impacts shall be analysed in light of the recovery process. Yet, recovery is defined in various ways. Some authors rely on an economic approach, considering that a community has recovered when financial and physical capital have exceeded pre-disaster levels (Kates et al., 2006). Others consider that recovery has been achieved when a community has regained a certain degree of autonomy and is able to sustain itself without external help (Le Masurier et al., 2006). Some highlight the role of demography, defining the recovery process as the repopulation of an affected community. Repopulation may occur by the return of evacuated or displaced inhabitants, or by the arrival of newcomers (Aldrich, 2012). This last approach emphasizes the unequal nature of recovery. Inasmuch as populations are not equal in this process, social and spatial disparities are then aggravated by the recovery process with potential consequences on the social fabric of communities, as outlined by the example of the New Orleans metropolitan area after Katrina (Falk et al., 2006; Green et al., 2007; Groen \& Polivka, 2010). If some researchers insist on the recovery process as a "window of opportunity" to prevent future disasters (Moatty \& Vinet, 2016), this paper strictly focuses on the study of those social and spatial disparities, and the capability of populations to recover from a disaster.

\subsection{Research relevance: scientific frame and methodological innovations}

\subsubsection{Exploring the issue of social and post-disaster impacts in Paris region}

At the scale of the Paris region, though flood hazard is now a well-documented topic, there are still several research orientations which should be studied more thoroughly in regard to post-disaster and social impacts analyses. Knowledge on post-disaster processes remains deficient regarding the Seine flood hazard, apart from studies on technical networks (Beraud, 2013; Toubin, 2014). Similarly, economic impacts of a major flood in 
the Paris region have now been assessed for several decades (IIBRBS, 1998; OECD, 2014), which is not yet the case for social impacts.

\subsubsection{A hybrid methodology: combining a vulnerability index and a damage model}

This research is also relevant in regard to the general literature on risks and natural hazards. Risk is generally defined as the convolution between hazards and the vulnerability of the elements at risk (Cardona, 2003; Hufschmidt, 2011). Hazards generally refer to the features of a damaging event, or its probability of occurrence (Dauphiné \& Provitolo, 2013). Approaches and definitions vary greatly amongst authors in respect to vulnerability (Adger, 2006; Hufschmidt, 2011). In this paper, vulnerability has been simply defined as the potential for losses of an element at risk (Alexander, 2000). It should not be confused with the concept of resilience, which refers to the ability to prepare for, recover from and adapt to disasters (Cutter et al., 2014). Different methods have been developed to assess vulnerability, particularly damage models and mapped vulnerability indexes. In this methodology, these two generic methods have been combined in an original fashion.

(1) Damage models aim at estimating damages (negative impacts) caused by a given hazard (Hubert and Ledoux, 1999), for different purposes (Eleuterio et al., 2008; Merz et al., 2010; Torterotot, 1993). Most of these models lead to a monetary assessment of damages to buildings and infrastructures (de Moel et al., 2015; Hammond, 2014). In this methodology, the damage model that has been developed allows measurement of the alteration of basic services and structures necessary for the everyday needs of the inhabitants. In this instance, we prefer to put aside the monetary logic that predominates most damage models for a more functional logic. Indeed, this study does not aim at assessing economic damage, but to assess the impact of the flood on the functioning of the territory in a systemic and global approach.

(2) Mapped vulnerability indexes aggregate variables in order to represent community or population vulnerability at the scale of residential blocks, municipalities, and counties (Cutter et al., 2010, 2003; Fekete, 2009; Flanagan et al., 2011; Koks et al., 2015; Rygel et al., 2006; Su et al., 2015). These indexes are however unfit for a study centered on a particular stage of a disaster. Rufat et al. (2015) highlight the temporal context of every vulnerability study - vulnerability factors are not the same depending on the disaster timing. A vulnerable person during the evacuation stage may not be vulnerable during the recovery stage. Thus, the few methods developed to map recovery capability or post-disaster displacement risk (Esnard et al., 2011; Finch et al., 2010; Myers et al., 2008) rely on a general state-of-the-art regarding vulnerability, and fail to fully consider the peculiarities of post-disaster situations. The index of vulnerability that has been developed in this paper, called Index of Social Destabilization (ISD), aims at representing the potential difficulties of a given population to recover in a post-disaster context. It differs from these former studies as it aggregates variables based upon specific literature aiming at identifying determinants of the recovery capability of populations.

To sum up, the objective of this analysis is to study post-disaster social impacts on a municipal scale, through the combination of a damage model and a spatialized index in a GIS. This methodology is applied to a case study related to a potential major flood of the Seine river and its tributaries in the Paris region. This paper is divided in three parts. First, a state-of-the-art of recovery determinants is synthesized. Second, methodology is presented. Third, results are featured and commented. 


\section{STATE OF THE ART: RECOVERY CAPABILITY DETERMINANTS}

For the assessment of post-disaster social impacts, it is crucial to identify the determinants of the populations' recovery after a disaster. This requires a state-of-the-art based upon social and demographic post-disaster studies.

\subsection{Social and demographic studies - an inventory}

The main quantitative studies used in the state-of-the-art are listed in table $\mathbf{1}^{4}$. Two kinds of quantitative studies are available: (a) demographic census analyses, which allow the observation of the consequences of a disaster on social and demographic trends (Kamel, 2012). (b) Analyses of post-disaster surveys conducted with affected households or individuals (Elliott, 2010). They both involve correlation and regression analyses of the collected data. Dependent variables nonetheless vary depending on the authors. Some study the return of inhabitants in their homes (Smith \& McCarty, 1996; Xiao \& Van Zandt, 2011). Others use self-reports done by the surveyed households of their own economic status (Bolin \& Bolton, 1986). Most of the studies rely however on the rate of demographic change in the affected communities (Aldrich, 2012; Shimada, 2015).

Table 1.

\section{State-of-the-art of quantitative studies concerning post-disaster recovery of populations and communities.}

\begin{tabular}{|c|c|c|c|c|c|c|}
\hline Authors (date) & Hazard & Study area & $\begin{array}{c}\text { Nature of the } \\
\text { study }\end{array}$ & $\begin{array}{c}\text { Surveyed } \\
\text { indiv/ } \\
\text { household }\end{array}$ & $\begin{array}{c}\text { Dependent } \\
\text { variable }\end{array}$ & $\begin{array}{l}\text { Duration of } \\
\text { the study }\end{array}$ \\
\hline Aldrich (2012) & $\begin{array}{l}\text { Great Hanshin } \\
\text { earthquake (1995) }\end{array}$ & $\begin{array}{l}\text { Kobe } \\
\text { Municipalities }\end{array}$ & $\begin{array}{l}\text { Demographic } \\
\text { trend analysis }\end{array}$ & & $\begin{array}{l}\text { Demographic } \\
\text { change rate }\end{array}$ & $1990-2008$ \\
\hline $\begin{array}{l}\text { Bolin \& Bolton } \\
(1986)\end{array}$ & $\begin{array}{l}\text { Tornado in Paris, } \\
\text { Texas (1982) }\end{array}$ & $\begin{array}{l}\text { Paris, Texas } \\
\text { (USA) }\end{array}$ & $\begin{array}{l}\text { Post-disaster } \\
\text { survey }\end{array}$ & 431 & $\begin{array}{l}\text { Economic } \\
\text { recovery of } \\
\text { households }\end{array}$ & $\begin{array}{l}8 \text { months } \\
\text { after disaster: }\end{array}$ \\
\hline Elliott (2010) & $\begin{array}{l}\text { Hurricane Katrina } \\
(2005)\end{array}$ & $\begin{array}{l}\text { Lower Ninth Ward } \\
\text { and Lakeview, } \\
\text { New Orleans }\end{array}$ & $\begin{array}{l}\text { Post-disaster } \\
\text { survey }\end{array}$ & 179 & Miscellaneous & $\begin{array}{l}9-16 \text { months } \\
\text { after disaster }\end{array}$ \\
\hline Kamel (2012) & $\begin{array}{l}\text { Hurricane Katrina } \\
(2005)\end{array}$ & $\begin{array}{l}\text { New Orleans } \\
\text { Metropolitain Area }\end{array}$ & $\begin{array}{l}\text { Demographic } \\
\text { trend analysis }\end{array}$ & - & $\begin{array}{l}\text { Repopulation } \\
\text { rate of } \\
\text { neighbour. }\end{array}$ & $2005-2010$ \\
\hline $\begin{array}{l}\text { Kamel \& } \\
\text { Loukaitou-Sideris } \\
(2004)\end{array}$ & $\begin{array}{l}\text { Earthquake in } \\
\text { Northridge (1994) }\end{array}$ & $\begin{array}{l}\text { Los Angeles } \\
\text { Metropolitan Area } \\
\text { (USA) }\end{array}$ & $\begin{array}{l}\text { Demographic } \\
\text { trend analysis }\end{array}$ & - & $\begin{array}{l}\text { Access to } \\
\text { institutional } \\
\text { funds }\end{array}$ & $1990-2000$ \\
\hline $\begin{array}{l}\text { Morrow-Jones \& } \\
\text { Morrow-Jones } \\
(1991)\end{array}$ & Miscellaneous & USA & $\begin{array}{l}\text { Demographic } \\
\text { trend analysis }\end{array}$ & - & \begin{tabular}{|l|} 
Permanent \\
displacements \\
of populations \\
\end{tabular} & $1974-1981$ \\
\hline Myers et al. (2008) & $\begin{array}{l}\text { Hurricanes Katrina } \\
\text { and Rita (2005) }\end{array}$ & $\begin{array}{l}\text { Gulf of Mexico } \\
\text { counties (USA) }\end{array}$ & $\begin{array}{l}\text { Demographic } \\
\text { trend analysis }\end{array}$ & - & $\begin{array}{l}\text { Outmigration } \\
\text { rate }\end{array}$ & $\begin{array}{l}10 \text { months } \\
\text { after disaster }\end{array}$ \\
\hline Shimada (2015) & Miscellaneous & $\begin{array}{l}\text { Japanese } \\
\text { Prefectures }\end{array}$ & $\begin{array}{l}\text { Demographic } \\
\text { trend analysis }\end{array}$ & - & \begin{tabular}{|l|} 
Demographic \\
change rate
\end{tabular} & 1981-2012 \\
\hline $\begin{array}{l}\text { Smith \& McCarty } \\
(1996)\end{array}$ & $\begin{array}{l}\text { Hurricane Andrew } \\
(1992)\end{array}$ & $\begin{array}{l}\text { Miami-Dade } \\
\text { County (USA) }\end{array}$ & $\begin{array}{l}\text { Post-disaster } \\
\text { survey }\end{array}$ & 5310 & \begin{tabular}{|l|} 
Return rate \\
(return to pre- \\
disaster)
\end{tabular} & $\begin{array}{l}1-2 \text { years } \\
\text { after disaster: }\end{array}$ \\
\hline $\begin{array}{l}\text { Xiao \& Van Zandt } \\
(2011)\end{array}$ & $\begin{array}{l}\text { Hurricane Ike } \\
(2008)\end{array}$ & $\begin{array}{l}\text { Galveston County } \\
\text { (USA) }\end{array}$ & $\begin{array}{l}\text { Post-disaster } \\
\text { survey }\end{array}$ & 980 & \begin{tabular}{|l|} 
Return rate \\
(return to pre- \\
disaster)
\end{tabular} & $\begin{array}{l}7 \text { months } \\
\text { after disaster }\end{array}$ \\
\hline Zhang (2006) & $\begin{array}{l}\text { Hurricane Andrew } \\
(1992)\end{array}$ & $\begin{array}{l}\text { South of Miami- } \\
\text { Dade County } \\
\text { (USA) }\end{array}$ & $\begin{array}{l}\text { Demographic } \\
\text { trend analysis }\end{array}$ & - & $\begin{array}{l}\text { Residential } \\
\text { property } \\
\text { values }\end{array}$ & $1992-1996$ \\
\hline
\end{tabular}

\footnotetext{
${ }^{4}$ Qualitative studies quoted in this paper are not listed in Table 1 for readability reasons.
} 


\subsection{Identifying predictive determinants for the recovery of populations}

Beyond the diversity of studies, some variables are regularly quoted as being potentially predictive of the capability of a given population, social group, household, or person to recover.

\subsubsection{Synthesis - predictive determinants for recovery}

Table 2 synthesizes those variables, which are grouped by factors. Amongst factors, a distinction has been made between pre-existing conditions and conditions created by the disaster occurrence. These variables are crucial to the understanding of the observed disparities - between communities and between affected populations - in the recovery stage. Three main factors emerge out of this set of variables - social capital, demographic, and socioeconomic individual status and post-disaster environmental conditions.

Table 2.

Post-disaster recovery determinants.

\begin{tabular}{|c|c|c|c|c|}
\hline Timing & Factors & Variables & $\begin{array}{c}\text { Impact on } \\
\text { recovery rate } \\
\text { / speed }\end{array}$ & Source (studies from table 1 ) \\
\hline \multirow{13}{*}{$\begin{array}{c}\text { Pre-disaster } \\
\text { conditions }\end{array}$} & \multirow{2}{*}{ Social capital } & Bonding & + & Aldrich (2012); Shimada (2015) \\
\hline & & Bridging & ++ & Elliott (2010); Shimada (2015) \\
\hline & \multirow{2}{*}{ Urbanisation } & Population / Building density & - & Myers et al. (2008) \\
\hline & & Multiple-dwelling buildings & - & Kamel (2012) \\
\hline & \multirow{3}{*}{$\begin{array}{l}\text { Demographic } \\
\text { status }\end{array}$} & Household size & - & Bolin \& Bolton (1986) \\
\hline & & Advanced age & - & $\begin{array}{l}\text { Morrow-Jones \& Morrow-Jones } \\
(1991)\end{array}$ \\
\hline & & $\begin{array}{l}\text { Woman as head of the } \\
\text { household }\end{array}$ & - & $\begin{array}{c}\text { Morrow-Jones \& Morrow-Jones } \\
(1991)\end{array}$ \\
\hline & \multirow{6}{*}{$\begin{array}{l}\text { Social and } \\
\text { economic status }\end{array}$} & Income & ++ & $\begin{array}{c}\text { Aldrich (2012); Kamel (2012); } \\
\text { Kamel \& Loukaitou-Sideris (2004); } \\
\text { Myers et al. (2008); Zhang (2006) }\end{array}$ \\
\hline & & Insurance cover & + & Bolin \& Bolton (1986) \\
\hline & & Education & + & $\begin{array}{l}\text { Morrow-Jones \& Morrow-Jones } \\
\text { (1991) }\end{array}$ \\
\hline & & Renter / Social housing & -- & Kamel (2012); Zhang (2006) \\
\hline & & Racial / Ethnic minority & -- & $\begin{array}{l}\text { Kamel (2012); Kamel \& Loukaitou- } \\
\text { Sideris (2004); Morrow-Jones \& } \\
\text { Morrow-Jones (1991); Zhang (2006) }\end{array}$ \\
\hline & & Immigrant status & - & Kamel \& Loukaitou-Sideris (2004) \\
\hline \multirow{5}{*}{$\begin{array}{c}\text { Post-disaster } \\
\text { conditions }\end{array}$} & $\begin{array}{l}\text { Physical } \\
\text { damages }\end{array}$ & $\begin{array}{c}\text { Hazard magnitude, residential } \\
\text { damages }\end{array}$ & - & $\begin{array}{l}\text { Kamel (2012); Myers et al. (2008); } \\
\text { Smith \& McCarthy (1996) }\end{array}$ \\
\hline & \multirow{2}{*}{$\begin{array}{l}\text { Environmental } \\
\text { conditions }\end{array}$} & Business recovery & + & Xiao \& Van Zandt (2011) \\
\hline & & $\begin{array}{l}\text { Departure of people from } \\
\text { surrounding communities }\end{array}$ & - & Myers et al. (2008) \\
\hline & \multirow{2}{*}{$\begin{array}{l}\text { Post-disaster } \\
\text { individual } \\
\text { itineraries }\end{array}$} & \begin{tabular}{|c|}
$\begin{array}{c}\text { Evacuation / Number of post- } \\
\text { disaster displacements }\end{array}$ \\
\end{tabular} & - & Bolin \& Bolton (1986) \\
\hline & & \begin{tabular}{|c|} 
Geographic distance (between \\
one's pre-disaster home and \\
shelter / temporary house)
\end{tabular} & - & Smith \& McCarthy (1996) \\
\hline
\end{tabular}

\subsubsection{Social capital}

Social capital appears nowadays at the centre of research on post-disaster recovery (Aldrich, 2012). Social capital is defined as the relationship between individuals. It is made of resources related to the belonging to a particular group (Bourdieu, 1980). The social capital of a given individual depends upon the size of the network he is able to mobilize. It is also related to the volume of the economic, symbolic, cultural capital of each person of 
his or her network. Social capital thus reproduces the inequalities observed in the distribution of economic, cultural, symbolic capital. After a disaster, social capital is crucial for recovery for several reasons. (a) Thanks to social capital, inhabitants can overcome collective problems that arise during the recovery stage. Amongst other things, they are able to mutualize means so as to speed up recovery. (b) People with strong social capital are also more strongly attached to their communities, and therefore more willing to stay or to come back to their communities. (c) Finally, they are able to regroup in community organizations in order to make demands to the local and national authorities to have a say in the official recovery projects (Shimada, 2015). Social capital has spatial implications in the recovery phase, as shown by Aldrich (2012) after the Great Hanshin earthquake in 1995, and Hurricane Katrina in 2005. A neighbourhood even highly damaged may recover while another may not, due to differences in social capital.

\subsubsection{Individual factors}

Individual status also plays a major role in recovery dynamics. On a demographic level, household configuration (gender, age, size) impacts recovery capability. Large households and families with children face pressures that other households do not - the former have more needs regarding public services, utilities, and educational systems (Paxson \& Rouse, 2008; Sastry, 2009). A high proportion of elderly persons in households has adverse effects on recovery processes, in contrast to a high proportion of working-age persons - as the latter have larger incomes (Arouri et al., 2015). At last, gender discriminations overlap other kinds of racial and socioeconomic discriminations. For instance, after the Red River flood in 1997 (USA), single mothers were overrepresented in the FEMA trailers (Enarson \& Fordham, 2001). On a socioeconomic level, there is a strong consensus between authors concerning income and economic capital variables (Carter et al., 2007; Green et al., 2007; Masozera et al., 2007). Higher incomes and savings allow people to recover quicker by their own means - for instance, rebuilding or finding another home. Similarly, owners may better recover than renters for several reasons - better economic situation, no rent to pay, and recovery policies favouring owners (Logan, 2006; Peacock et al., 2007; Whittle et al., 2010; Zhang, 2006; Zhang \& Peacock, 2009). Finally, ethnic and racial status may also be a determinant for recovery (Fothergill et al., 1999). Minorities may not recover as quickly as the majority, for at least two reasons: (1) they have lower incomes and capital (Arouri et al., 2015); (2) racial discriminations by populations and administrations may exist which impact the recovery process.

\subsubsection{Post-disaster conditions}

Finally, the post-disaster environment may also impact the recovery rate and speed. The damage rate of infrastructures, utilities, businesses and dwellings is of course a crucial factor in the recovery process (Paxson \& Rouse, 2008). In an obvious way, recovery is harder and slower when damages are high. Populations may not return to their former communities if businesses are closed, and water or energy utilities are shut down, and it may be difficult for parents to go back to work if schools are still closed and unable to receive their children. Conversely, if populations do not come back to their communities, companies and authorities will not be enticed to invest in rebuilding utilities or reopening public services. Nevertheless, some authors have highlighted the fact that a disaster is also an opportunity to "build back better", which is easier when damages are so high that it is possible and less expensive to make tabula rasa (Aldrich, 2012). In contrast, this option is harder to implement when damages are moderate (when it is not required to rebuild but to repair). 


\section{METHODOLOGY}

The methodology developed for quantitative and cartographic estimation of postdisaster social impacts is based on a combination of two models. On the one hand, it relies on a damage model, which aims at estimating the alteration of basic services and structures essential to the daily life of the populations. On the other hand, it is based upon the mapping of an Index of Social Destabilization (ISD). This spatialized index represents the susceptibility of a given population to undergo the negative impacts of a disaster in the long term, seen as an inverse function of its ability to recover. The damage model is determined by environmental variables characterizing the living conditions in a post-disaster situation. Conversely, recovery capability is estimated from individual and collective social variables, which characterize the exposed populations prior to the disaster.

\subsection{Community damage model}

The community damage model aims at estimating the degradation of services essential to the daily life of populations. These services are considered to be crucial to the return of inhabitants to their former homes or communities.

\subsubsection{Identifying services conditioning the return of populations on an affected community}

This model is based primarily on the identification of four types of structures and infrastructures hosting these basic services: housing, primary schools, food shops and supermarkets, railway stations and service stations of the rail network. The choice in this area is based on conceptual and practical reasons. From a practical point of view, the number of structures identified is limited in order to ensure the clarity of the model and its reproducibility. It must also be possible to find corresponding geolocated data, preferably free access. In this case, housing data is derived from a cross-referencing of the $\mathrm{IGN}^{5}$, the Iau-Idf ${ }^{6}$ and INSEE $^{7}$ databases. This cross-referencing makes it possible to locate residential buildings in the Paris region, and to estimate within each building the number of dwellings and inhabitants. The method used to make these estimates is adapted from the one used by Ast for example (2008), or by the CGDD (Office of the Commissioner-General for Sustainable Development and the Observation and Statistics Service, 2012) to estimate the number of people in the flood area. Transport infrastructure data is taken from the $\mathrm{STIF}^{8}$ database, and business and public services data from an INSEE database on Permanent Facilities (BPE).

From a conceptual point of view, the choice of structures and infrastructures is based on the state-of- the- art drawn up previously on the post-disaster environment. Damages to businesses are central in the return (or not) of populations in a disaster area (Xiao \& Van Zandt, 2011). This analysis is limited to retail trade as they are at the core of a district or town's life. They also are essential in case of crisis in order to supply populations with basic necessities. The availability of public transport is also essential to enable people to go to work, to cover their daily needs, to acquire basic necessities, to have access to medical facilities, and to be able to see their relatives and friends (Wright \& Johnston, 2010). The

\footnotetext{
5 "BD Topo" - topographic data (IGN: National Institute of Geographical and Forestry Information).

6"BD MOS" - land cover data (Iau-Idf: Institute of Planning and Urban Development of the Ile-deFrance region).

7 "BD RGP" - population and dwelling data available at the census block scale (INSEE: National Institute of Itatistics and Economic Studies).

${ }^{8}$ STIF: Ile-de-France Transport Authority.
} 
availability of public services is also an essential condition for recovery. Public services include schools, kindergartens and day care centers, as well as libraries (Groen \& Polivka, 2010). However, it is the nursery and primary schools which are the keystone of the life of a district or town, allowing parents of young children to return to work during the working hours, and therefore allowing populations to return to a form of routine. Schools represent the reference local service, which need to be located very close to accommodations, unlike other public services. Finally, the availability of housing is a key factor in the return of the population. The latter must have a place to live and reside, which appears difficult in a context where the housing stock is partly damaged or destroyed.

\subsubsection{Hazard Parameters and Damage Thresholds}

Once these structures and infrastructures have been identified, it is necessary to estimate their potential damage. As a reminder, flooding causes a physical impact on the structure, as much by the prolonged contact of the water on the materials (capillarity effect), as by the hydrostatic effects (water levels) and the dynamics of the water (flow velocity, impact of floating objects) on structures (Salagnac et al., 2014, Torterotot, 1993). Multiple studies agree that the damage to the structure is effective if the water height levels are greater than or equal to one meter, or if the flood duration exceed 72 hours (CEPRI, 2012; Salagnac et al., 2014; Torterotot). Under these conditions, the finishing components of the building (secondary work), in some cases the shell (main work), must be rebuilt, which requires several months to several years. Uncertainties regarding the recovery time are numerous 9 .

\subsubsection{Model implementation with GIS}

The model is implemented in a GIS, in two stages. First, it is necessary to cross the data related to the structures and infrastructures identified in the Paris region to the data on hazard parameters (water levels and flood duration). The water depth data used are surface data called Potential Flood Areas, available for various flood scenarios thanks to the mapping work of the DRIEE ${ }^{10}$ and the SGZDS-Paris ${ }^{11}$. They were developed by the latter by crossing a hydraulic model (Alphee model - IIBRBS, 1998), and a Digital Elevation Model obtained by a LIDAR campaign (DRIEE and SGZDS-Paris, 2015). Ten flood scenarios were developed for the application of these Potential Flood Areas, from the "R0.5" scenario to the "R1.15" scenario: the figure is a coefficient, expressing the percentage of flood flow achieved during the January 1910 flood event. This article considers two scenarios: the scenario "R1" (100\% of the flood discharge of 1910), and the scenario "R1.15" (115\% of the flood discharge of 1910, that is the height reached by the latter at the Austerlitz hydrometric station in Paris ${ }^{12}$ ).

These two scenarios are scenarios of major flooding, of potential disasters, well-known by risk managers in the Paris region. The second scenario (R1.15) also makes it possible to

\footnotetext{
${ }^{9}$ In addition to hazard parameters, building protection and prevention measures can also limit (or worsen) the physical impact of flooding (CEPRI 2012, Salagnac et al., 2014). These measures are not studied here because it is not possible to obtain this type of data at the regional scale, and because they have a low impact (in particular for cofferdam type measurements) in case of a longterm flood. Plus, the purpose of the damage model is not to give an accurate estimate on a quantitative or spatial level, but to report the post-disaster situation on an overall state, summarized at the regional, departmental or municipal level.

${ }^{10}$ DRIEE: Regional and Interdepartmental Directorate of Environment and Energy.

${ }^{11}$ SGZDS-Paris: General Secretariat at the Defense and Security Zone of Paris.

${ }^{12}$ The difference between flow and height is explained by the hydraulic developments that have been carried out since 1910 (EPTB Seine Grands Lacs, 2014).
} 
study the significant threshold effects that characterize the Seine flood. The feedback from the recent floods (June 2016 in particular) cannot be used because the hydrological phenomena are not comparable and because they represent much more modest scenarios than those we study. The duration of submersion is deduced by simplification of the Alphee hydraulic model (Fujiki, 2017). In a second step, these crossed data are aggregated on a municipal or municipal district level. The data is aggregated on a municipal level because the municipality is the reference administrative level on a local scale, particularly for crisis management (Gralepois, 2008). It is also the oldest local institution, which continues to forge communities' identity: this is essential because of the role of social capital in populations capabilities to recover in post-disaster situations. The results come in the form of a ratio: structures and infrastructures damaged in relation to the total number of structures and infrastructures. A ratio is separately calculated for each type of structure and infrastructure (schools, shops, train stations, dwellings). The resulting four ratios are then summarized as an unweighted average.

\subsection{The Index of Social Destabilization (ISD)}

The computation of community damage makes it possible to estimate the practical ability of populations to be able to return to their homes or communities of origin. It comes with the calculation of the ISD, which makes it possible to estimate the intrinsic capability of these populations to recover.

\subsubsection{ISD potential variables}

The ISD is a composite index aggregating a set of variables on a municipal scale. The variables are chosen according to practical and conceptual considerations. From a conceptual point of view, the ISD is based on the state-of-the-art previously described: it aggregates the identified individual and collective variables, which may characterize a population in its capability to recover a priori. For each variable identified in the state-ofthe-art, the objective is to find at least two indicators to represent it. From a practical point of view, it is also necessary to find indicators that can represent these variables on a municipal scale. These indicators must come from reliable, comprehensive sources throughout the Paris region and be relatively recent. Care must be taken to limit the number of sources used in order to avoid the constraints related to their heterogeneity and the issues of methodological compatibility. As a result, most of this data is made available by INSEE (RGP, RFL ${ }^{13}, \mathrm{DADS}^{14}$ ), although data from the Ministry of the Interior and the ONDRP ${ }^{15}$ are also used. Considering all these issues, the working data matrix of our index comprises 25 potential variables. Specific constraints arise in representing social capital since it is never directly measured, in contrast to individual variables related to the demographic or socio-economic status of individuals. Social capital can only be indirectly estimated (Shimada, 2015). As such, previous studies have identified various indicators to represent bonding-type social capital: the ratio between the number of associations created and the number of inhabitants inside a community, the residence time spent in the neighbourhood (Aldrich, 2012), income homogeneity or suicide rate (Shimada, 2015). To represent bridging-type capital, other proxies have been identified: crime rate (Shimada, 2015), and participation in political elections (Aldrich, 2012).

\footnotetext{
${ }^{13}$ Geolocated Data on Tax Revenues.

${ }^{14}$ Annual Declaration of Social Data.

${ }^{15}$ ONDRP: National Observatory on Delinquency and Penal Responses.
} 


\subsubsection{Finalization of the index and statistical tests}

A composite index, such as the ISD, is considered valid if it is conceptually coherent and statistically robust. Conceptual consistency of the index is ensured through the state-ofthe-art drawn up to constitute it. Statistical robustness is checked in several steps, based on a set of methods applied particularly to the development of synthetic indexes of vulnerability. Before the data can be processed, a statistical refining (using R) is required. This refining includes rationalization and normalization of the indicators used. Rationalization consists of transforming absolute variables into relative variables (in percentage and density functions), in order to be able to compare heterogeneous municipalities both in terms of area and population (Cutter et al., 2010). Normalization makes it possible to compare indicators with each other and thus to aggregate them, regardless of the units of measurement. Normalization methods are multiple, but we have chosen the z-score method as it moderately takes into account the impact of extreme values (OECD, 2008). For a given indicator, normalization takes place so that a positive value represents a negative impact on the recovery capability.

Statistical refining also includes the imputation of missing data: concerning income data, statistical secrecy is essential for some small municipalities, which are therefore not included in the list. In the statistical tests that follow, the missing data is replaced by the average. Other methods exist, but they present significant methodological problems (OECD, 2008). A rudimentary method was thus preferred, albeit readable and easily reproducible. The final step in statistical refining includes the elimination of redundant indicators, through a Pearson correlation test: correlated indicators above the 0.9 threshold are removed (Su et al., 2015). This procedure removes statistical duplicates that could result in the overrepresentation of a given phenomenon in the synthetic index. It also makes it possible to limit the number of indicators constituting the index and to improve its methodological transparency (OECD, 2008). Subsequently, our data matrix is reduced to 22 indicators. However, a synthetic index of 22 indicators is difficult to interpret: Therefore, it is necessary to analyse the underlying structure of the index, which implies subdividing it into sub-indices or dimensions (OECD, 2008). Two approaches coexist (Cutter et al., 2003, 2010, 2014): a deductive approach and an inductive approach. The deductive approach consists in creating sub-indices based on the state-of-the-art of the researcher, without any prior analysis of the data structure. It has the disadvantage of being based on a personal appreciation of the index and its structure. We prefer the inductive approach based on a statistical analysis of the data matrix. The inductive approach is based upon a Principal Component Analysis (PCA), consisting in grouping correlated variables into principal components uncorrelated among themselves. These principal components constitute the dimensions or sub-indices of our synthetic index. Before applying PCA, it must be verified that the variables in our data matrix can be grouped together through appropriate statistical tests (Wolf and McGregor, 2013). Bartlett's sphericity test aims to refute the null hypothesis that there are no observed relationships between the variables in the data table. This test, successful in our case, remains however insufficient because it is biased when the number of observations is high. The Kaiser-Meyer-Olkin Sampling Precision Test (KMO) completes the analysis by comparing the magnitude of the correlation coefficients to the magnitude of the partial correlation coefficients, in the form of an index ranging from 0 to 1. This makes it possible to check that the variables can be clustered, and to delete the isolated variables from the rest of the data matrix. A KMO index can be computed for each variable and for the entire matrix. The OECD recommends deleting the variables with the lowest KMO until reaching a global KMO of 0.8 (OECD, 2008). Two variables are thus 
deleted, to finally obtain a matrix of 20 variables characterized by a KMO of 0.89 . Lastly, PCA may be computed. Four main components are retained with an eigenvalue greater than 1 (Cutter et al., 2003), explaining $70 \%$ of total variance of the data matrix. A varimax rotation of these four components is performed to maximize correlation of variables with a given component and to minimize correlation with the other components (Cutter et al., 2003, Su et al., 2015). Table 3 describes these four components and the variables most correlated with them. Each component represents one dimension of our index. The value of each dimension is computed for each municipality, based upon the coordinates of principal components. The weighted mean is then computed to obtain the Index of Social Destabilization (ISD). The weighting method is based upon the proportion of total variance that each component explains. This is the weighting method chosen by many authors (Myers et al., 2008), although some authors prefer to avoid weighting components (Cutter et al., 2010; Lee, 2014), while others have proposed alternative methods: the Pareto rank method (Rygel et al., 2006) or hierarchical analysis using the Saaty method (Barbat 2003, Barczak \& Grivault 2007).

Table 3.

Variables and principal components constituting the ISD.

\begin{tabular}{|c|c|}
\hline Principal Component & Variables \\
\hline \multirow{10}{*}{ Social capital - Family and demographic situation } & Abstention rate in municipal elections \\
\hline & Abstention rate in presidential elections \\
\hline & Population able to vote ${ }^{16}$ \\
\hline & Rate of violence to persons \\
\hline & $\%$ of large families ( $3+$ children) \\
\hline & $\%$ women head of households \\
\hline & $\%$ of households in building \\
\hline & Unemployment rate \\
\hline & $\%$ of people in social housing or housed for free \\
\hline & $\%$ of immigrants \\
\hline \multirow{4}{*}{ Wages and level of qualification } & Median revenue \\
\hline & Average hourly net salary \\
\hline & $\%$ of graduates of higher education \\
\hline & $\%$ of non-graduates \\
\hline \multirow{2}{*}{ Working conditions } & Part of employed part-time \\
\hline & Share of stable employment among employees \\
\hline \multirow{4}{*}{ Urban environment and socio-economic inequalities } & Number of inhabitants $/ \mathrm{km}^{2}$ \\
\hline & GINI index \\
\hline & Residence time greater than or equal to 5 years \\
\hline & $\%$ single women \\
\hline
\end{tabular}

\section{RESULTS AND CONCLUSION}

Through the implementation of our methodology, it is possible to compute, for each municipality, the intrinsic recovery capability of its population (via the IDS) and the community damage ratios following a large flood of the Seine (scenarios "R1" and "R1.15"). Crossing the two analyses makes it possible to identify municipalities whose population is particularly vulnerable during the recovery phase. 


\subsection{ISD mapping and recovery capabilities}

As a first step, it is possible to identify, on a spatial level, the distribution of geographical disparities in the recovery capability of populations (Fig. 1). A three-fold finding emerges: first, an urban centre characterized by a higher index, and therefore a weaker recovery capability; then, an opposition between East and West Paris, in favour of the second; finally, the identification of small islands of high values, in Seine-Saint-Denis, in the "Seine" part of Val-de-Marne, in the southern suburbs in Essonne, and in the northern suburbs in the Val d'Oise.
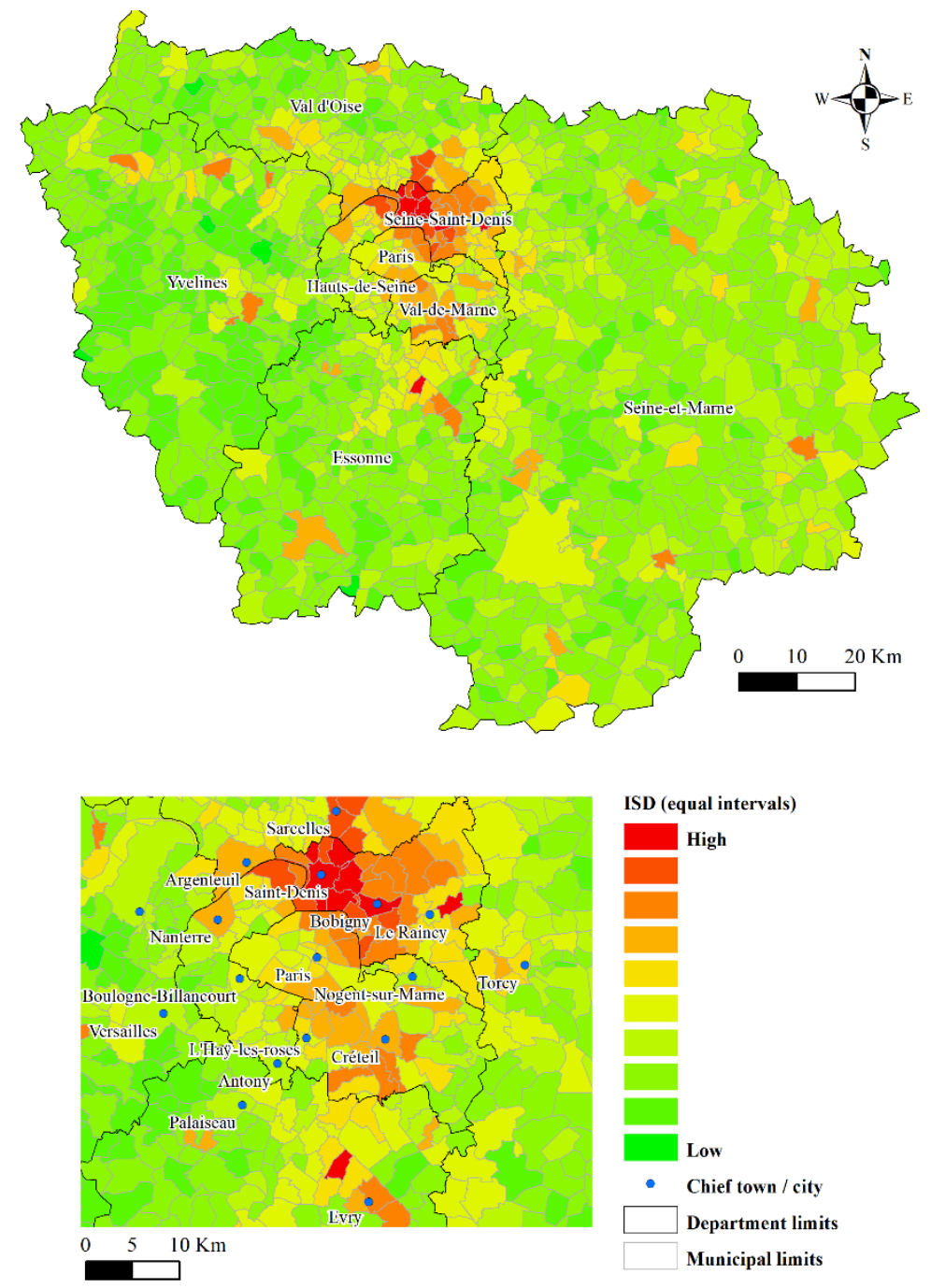

Fig. 1. Mapping the social destabilization index in Paris region.

Various explanations can be put forward, particularly by looking at Fig. 2, which represents the different components of the social destabilization index. Without detailing these components, the impact of urban density can be seen, as well as the distribution of 
income. Indeed, the mapping of the ISD covers, at least partially, that of the socio-spatial disparities that affect the Paris region (Bourdeau-Lepage, 2013; Gilli, 2014; Tovar \& Bourdeau-Lepage, 2013).

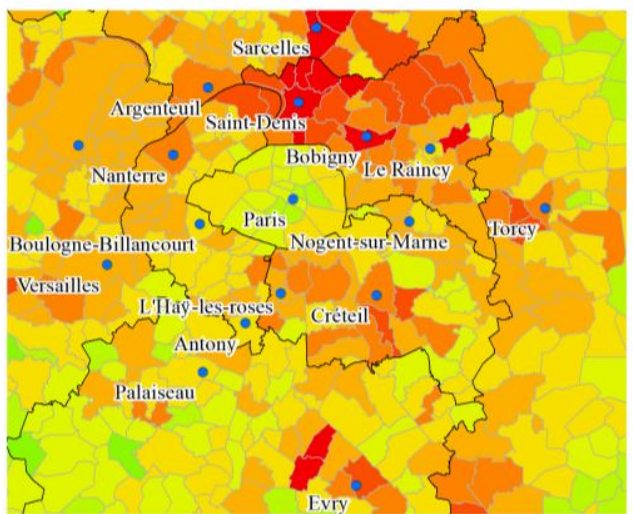

Social capital -

Family and demographic situation

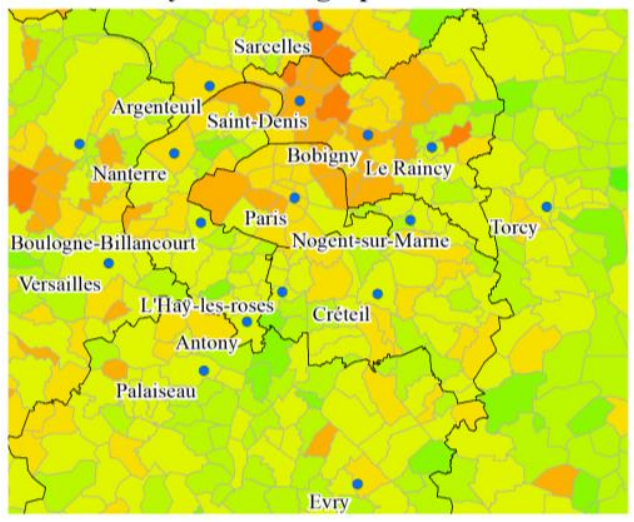

Working conditions

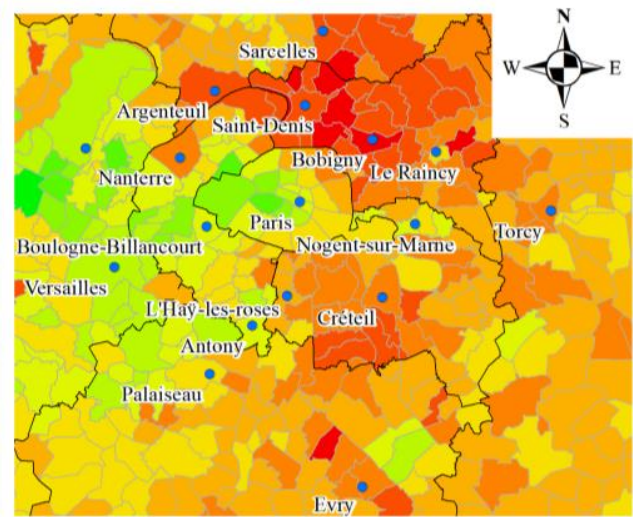

Wages and level of qualification

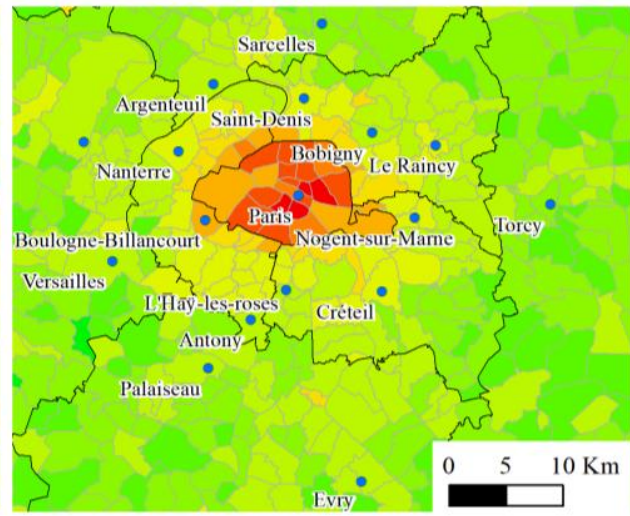

Urban environment and socio-economic inequalities

ISD (equal intervals)

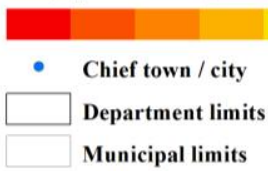

Fig. 2. Decomposition of IDS in principal components in the four central departments of Paris region.

\subsection{Cross analysis of community damage ratios and recovery capability: quantified estimates and mapping}

The mapping of ISD, however, is of operational interest only when faced with the estimation of community damage caused by flood scenarios. This estimation, however, must be taken with hindsight because it is very dependent on the quality of the data available. 
On a regional level, community damage caused by a flood of discharge equal to or greater than that of the flood of January 1910 may seem relatively moderate: less than five percent of the structures and basic infrastructures are damaged for a R1.15 scenario. These figures highlight, however, a strong threshold effect between scenario R1 and R1.15: the rise in the water level of a few tens of centimetres has multiplier effects, with a doubling of the damage levels (Fig. 3). They also show strong disparities in the exposure of communities, to the detriment of the departments of the inner suburbs (former zones of flood expansion). For the R1 scenario, the Val-de-Marne appears by far the department the most exposed (7.7\% damage). Hauts-de-Seine department may also appear as highly damaged under the R1.15 scenario (9.2\% damage for the latter, $12.1 \%$ for Val-de-Marne in this scenario).

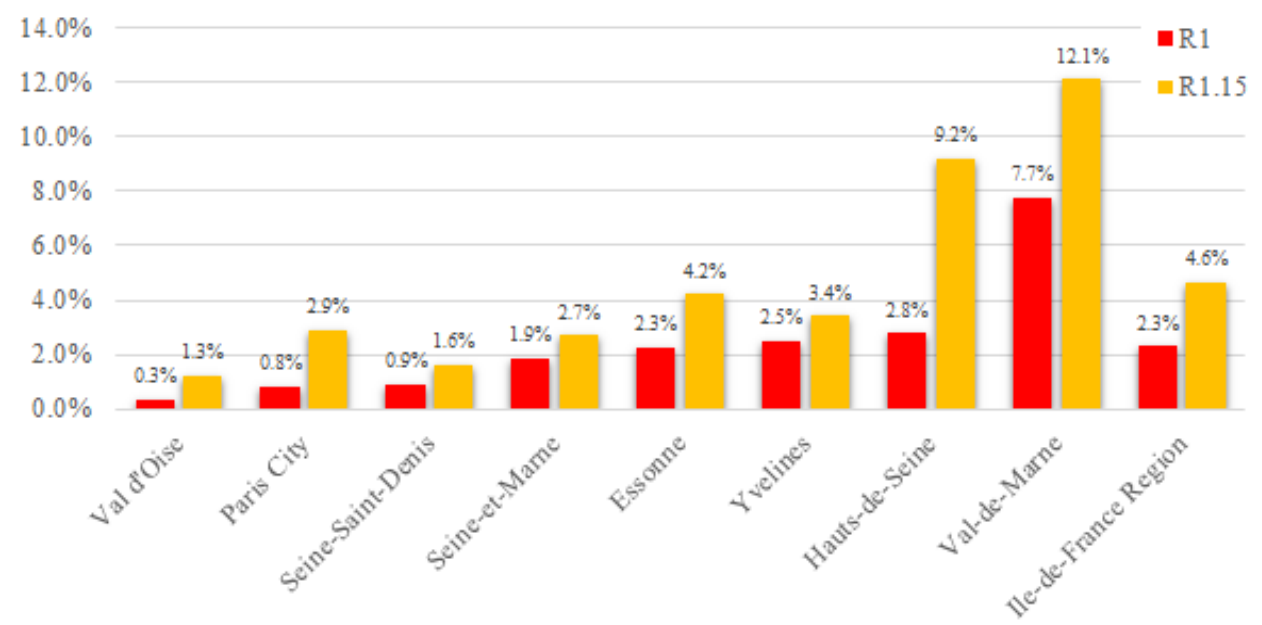

Fig. 3. Summary of community damage by department, for flood scenarios R1 and R1.15.

These disparities are even greater at the scale of municipalities (Fig. 4, Table 4). It is therefore possible to observe that, although regional damage ratios remain moderate, this is not the case on a lower level. Long-term social impacts remain a problem whose effects are felt most on a local scale. Thus, for a R1.15 scenario, the municipalities of Villeneuve-laGarenne (Hauts-de-Seine), Alfortville (Val-de-Marne), Viry-Châtillon (Essonne) are characterized by a damage ratio superior to $50 \%$ of their basic structures and infrastructure. More broadly, twenty municipalities (amongst those with more than 10,000 inhabitants) have to deal with a damage ratio superior to $20 \%$.

Crossing community damage and ISD values allows the identification of particularly vulnerable municipalities. Thus, table 4 ranks municipalities according to the Index of Social Destabilization, according to damage ratios, and to the two combined factors. A geography of post-disaster vulnerabilities is then possible: the most sustainable postdisaster social impacts can then be identified within municipalities that combine the high damage and the high destabilization index. In the latter, the population is not only vulnerable, but it also faces severely degraded post-disaster environmental conditions, in terms of access to public services, housing, transport and businesses that are essential to daily life. As such, the municipalities of Villeneuve-la-Garenne, Gennevilliers (Hauts-deSeine), Villeneuve-Saint-Georges (Val-de-Marne), appear as communities to prioritize during the recovery stage. 


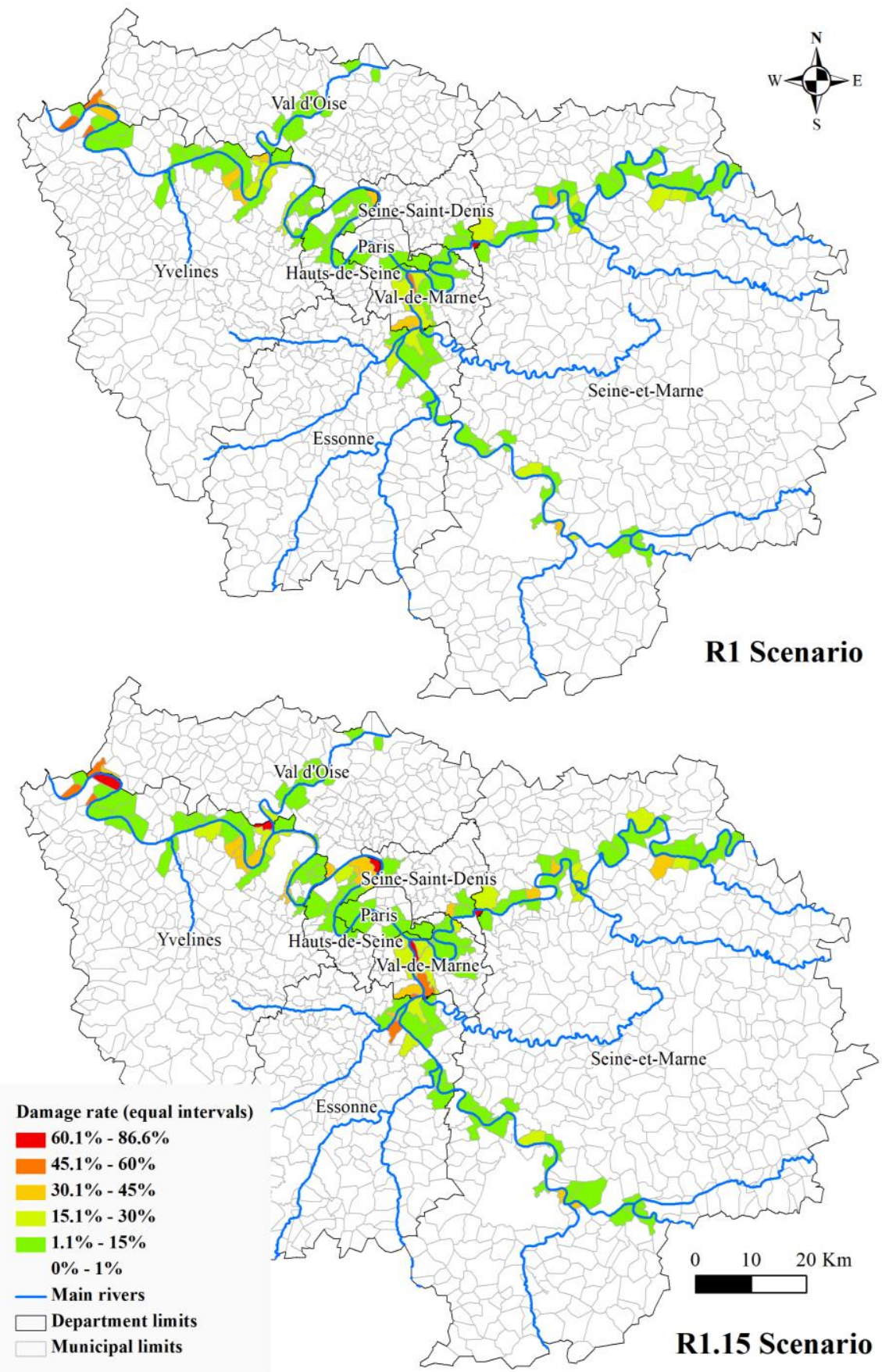

Fig. 4. Community damage ratio mapping in Paris region. 
Table 4.

Classification of municipalities with more than 10,000 inhabitants according to the index of social destabilization and community damage ratio, for a R1.15 flood scenario.

\begin{tabular}{|c|c|c|c|c|c|}
\hline \multirow{2}{*}{ Municipality name } & \multicolumn{2}{|c|}{ ISD } & \multicolumn{2}{|c|}{ Damage ratio } & \multirow[t]{2}{*}{ Mean rank (ISD + Damage) } \\
\hline & Value & Rank & $\%$ & Rank & \\
\hline VILLENEUVE-LA-GARENNE & 1,6 & 4 & $75 \%$ & 1 & 1 \\
\hline GENNEVILLIERS & 1,8 & 1 & $44 \%$ & 5 & 2 \\
\hline VILLENEUVE-SAINT-GEORGES & 1,6 & 5 & $50 \%$ & 4 & 3 \\
\hline ALFORTVILLE & 1,2 & 11 & $62 \%$ & 2 & 4 \\
\hline VIRY-CHATILLON & 0,8 & 20 & $52 \%$ & 3 & 5 \\
\hline VILLENEUVE-LE-ROI & 0,9 & 19 & $43 \%$ & 6 & 6 \\
\hline IVRY-SUR-SEINE & 1,5 & 7 & $26 \%$ & 18 & 6 \\
\hline BEZONS & 1,1 & 14 & $31 \%$ & 11 & 6 \\
\hline VITRY-SUR-SEINE & 1,3 & 10 & $27 \%$ & 17 & 9 \\
\hline VALENTON & 1,5 & 6 & $19 \%$ & 21 & 9 \\
\hline LES MUREAUX & 1,6 & 3 & $16 \%$ & 25 & 11 \\
\hline VIGNEUX-SUR-SEINE & 1,0 & 17 & $29 \%$ & 13 & 12 \\
\hline MONTEREAU-FAULT-YONNE & 1,7 & 2 & $14 \%$ & 31 & 13 \\
\hline ASNIERES-SUR-SEINE & 0,7 & 23 & $31 \%$ & 10 & 13 \\
\hline CLICHY & 1,3 & 9 & $15 \%$ & 26 & 15 \\
\hline CHOISY-LE-ROI & 1,1 & 13 & $17 \%$ & 23 & 16 \\
\hline JUVISY-SUR-ORGE & 0,6 & 28 & $39 \%$ & 8 & 16 \\
\hline COLOMBES & 1,0 & 16 & $21 \%$ & 20 & 16 \\
\hline CARRIERES-SOUS-POISSY & 0,7 & 25 & $31 \%$ & 12 & 19 \\
\hline NEUILLY-PLAISANCE & 0,5 & 31 & $42 \%$ & 7 & 20 \\
\hline CRETEIL & 1,1 & 12 & $15 \%$ & 27 & 21 \\
\hline RIS-ORANGIS & 0,9 & 18 & $18 \%$ & 22 & 22 \\
\hline CHELLES & 0,6 & 29 & $29 \%$ & 14 & 23 \\
\hline ACHERES & 0,6 & 30 & $27 \%$ & 16 & 24 \\
\hline CORBEIL-ESSONNES & 1,4 & 8 & $12 \%$ & 39 & 25 \\
\hline MAISONS-ALFORT & 0,5 & 32 & $27 \%$ & 15 & 25 \\
\hline LE PECQ & 0,2 & 44 & $37 \%$ & 9 & 27 \\
\hline PARIS 15E ARRONDISSEMENT & 0,7 & 24 & $14 \%$ & 30 & 28 \\
\hline ATHIS-MONS & 0,7 & 26 & $14 \%$ & 33 & 29 \\
\hline GAGNY & 0,8 & 21 & $9 \%$ & 43 & 30 \\
\hline PONTOISE & 1,0 & 15 & $5 \%$ & 50 & 31 \\
\hline SAINT-MAURICE & 0,5 & 36 & $14 \%$ & 32 & 32 \\
\hline JOINVILLE-LE-PONT & 0,5 & 34 & $13 \%$ & 35 & 33 \\
\hline PARIS 12E ARRONDISSEMENT & 0,6 & 27 & $9 \%$ & 42 & 33 \\
\hline ANDRESY & $-0,1$ & 50 & $23 \%$ & 19 & 33 \\
\hline ISSY-LES-MOULINEAUX & 0,3 & 41 & $15 \%$ & 29 & 36 \\
\hline BRY-SUR-MARNE & $-0,0$ & 47 & $17 \%$ & 24 & 37 \\
\hline LE PERREUX-SUR-MARNE & 0,2 & 43 & $15 \%$ & 28 & 37 \\
\hline LAGNY-SUR-MARNE & 0,5 & 35 & $12 \%$ & 37 & 39 \\
\hline PARIS 4E ARRONDISSEMENT & 0,8 & 22 & $5 \%$ & 51 & 40 \\
\hline BOULOGNE-BILLANCOURT & 0,4 & 38 & $13 \%$ & 36 & 41 \\
\hline CHARENTON-LE-PONT & 0,5 & 33 & $8 \%$ & 45 & 42 \\
\hline SAINT-MAUR-DES-FOSSES & 0,1 & 45 & $14 \%$ & 34 & 43 \\
\hline
\end{tabular}




\begin{tabular}{|l|r|r|r|r|r|} 
DRAVEIL & 0,4 & 39 & $9 \%$ & 41 & 44 \\
\hline VAIRES-SUR-MARNE & 0,4 & 37 & $9 \%$ & 44 & 45 \\
\hline RUEIL-MALMAISON & $-0,0$ & 46 & $12 \%$ & 38 & 46 \\
\hline LEVALLOIS-PERRET & 0,4 & 40 & $8 \%$ & 47 & 47 \\
\hline PARIS 8E ARRONDISSEMENT & 0,2 & 42 & $8 \%$ & 46 & 48 \\
\hline SAINT-CLOUD & $-0,2$ & 51 & $10 \%$ & 40 & 49 \\
\hline VERNEUIL-SUR-SEINE & $-0,0$ & 48 & $7 \%$ & 48 & 50 \\
\hline NEUILLY-SUR-SEINE & $-0,1$ & 49 & $6 \%$ & 49 & 51 \\
\hline
\end{tabular}

\subsection{Conclusions}

To conclude, this study is based on the combination of an analysis of social variables, expressing the intrinsic recovery capability of populations, and a community damage model, based on the analysis of environmental variables relating to flood hazard. In this way, it is possible to estimate post-disaster social impacts at the level of municipalities in the Paris region.

If reconstruction must be managed on a macro-geographic scale, through regional and national steering to mobilize massive logistical, financial and organizational means, longterm social impacts are felt primarily at the local scale. Municipalities characterized by both severe damage and weak recovery capability are likely to experience the most profound post-disaster changes in their socio-demographic profile: from the replacement of a given population by another to potential local desertification of the disaster area. Recovery is indeed a period marked by divergent territorial trajectories, which reproduce and accentuate pre-existing social and spatial disparities. Yet, recovery policies generally focus on physical capital reconstruction, neglecting social capital recovery and sometimes aggravating spatial inequalities in the recovery process (Aldrich, 2012, Gotham \& Greenberg, 2014, Gotham, 2015). In order to avoid these pitfalls, the municipalities thus identified through our methodology must be the subject of in-depth consideration by the authorities of the Paris region in the planning process prior to the disaster.

\section{Acknowledgements}

The authors are grateful to the two anonymous reviewers for their useful comments. They would also like to thank Pr. Michel Mietton (University Lyon 3) for his help. At last, they would like to thank the Prefectoral Police of Paris and the Defense and Security Area of Paris for their support, as well as the research project team of EURIDICE (Equipe Universitaire sur les Risques, Dispositifs de Gestion de Crise et des Evénements Majeurs).

\section{R E F E R E N C E S}

Adger, W. (2006) Vulnerability, Global Environmental Change, 16, 268-281.

Ahern, M., Kovats, R.S., Wilkinson, P., Few, R. \& Matthies, F. (2005) Global Health Impacts of Floods: Epidemiologic Evidence, Epidemiologic Reviews, 27, 36-46.

Aldrich, D. (2012) Building resilience. Social capital in post-disaster recovery, Chicago, London, The University of Chicago Press.

Alexander, D. (2000), Confronting catastrophe. New perspectives on natural disasters, Oxford, Oxford University Press.

Arouri, M., Nguyen, C. \& Ben Youssef, A. (2015) Natural disasters, household welfare, and resilience: evidence from rural Vietnam, World Development, 70, 59-77. 
Ast, J.-P. (2008) Etude sur la vulnérabilité des territoires essonniens face au risque inondation (Travail de Fin d'Etude. Cycle des Ingénieurs diplômés de 3ème année), Champs sur Marne, Ecole Nationale des Sciences Géographiques.

Baade, R., Baumann, R. \& Matheson, V. (2007) Estimating the economic impact of natural and social disasters, with an application to hurricane Katrina, Urban Studies, 44, 2061-2076.

Barbat, A. (2003) Detailed application of the holistic approach for seismic risk evaluation in an urban center using relative indices. Manizales, Universidad Nacional de Colombia, Information and Indicators Program for Disaster Risk Management.

Barczak, A. \& Grivault, C. (2007) Système d'information géographique pour l'évaluation de la vulnérabilité au risque de ruissellement urbain, in: 6th International Conference on Sustainable Techniques and Strategies in Urban Water Management, Novatech, Lyon.

Beraud, H. (2013) Initier la résilience du service de gestion des déchets aux catastrophes naturelles: le cas des territoires urbains et de l'inondation (PhD Thesis), Marne-la-Vallée, Université ParisEst.

Bolin, R. \& Bolton, P. (1986) Race, religion, and ethnicity in disaster recovery (FMHI Publications No. 88), Tampa, Louis de la Parte Florida Mental Health Institute (FMHI), University of South Florida.

Bolin, R. \& Stanford, L. (1991) Shelter, housing and recovery: a comparison of US disasters, Disasters, 15, 24-34.

Bourdeau-Lepage, L. (2013) Introduction. Grand Paris : projet pour une métropole globale, Revue d'Economie Régionale et Urbaine, 2013/3, 403-436.

Bourdieu, P. (1980) Le capital social, Actes de la recherche en sciences sociales, 31, 2-3.

Brémond, P., Grelot, F. \& Agenais, A.-L. (2013) Review Article: Economic evaluation of flood damage to agriculture - review and analysis of existing methods, Natural Hazards and Earth System Sciences, 13, 2493-2512.

Cardona, O. (2003) The need for rethinking the concepts of vulnerability and risk from a holistic perspective: a necessary review and criticism for effective risk management, in: Mapping Vulnerability: Disasters, Development and People, London, Earthscan, 37-51.

Carter, M., Little, P. \& Mogues, T. (2007) Poverty traps and natural disasters in Ethiopia and Honduras, World Development, 35, 835-856.

CEPRI (2012) Le bâtiment face à l'inondation. Diagnostiquer et réduire sa vulnérabilité (Les guides du CEPRI). Orléans.

CEPRI (2014) L'évacuation massive des populations. Les territoires face à l'inondation (Les guides du CEPRI). Orléans.

Chocat B. (1997) Encyclopédie de l'hydrologie urbaine et de l'assainissement. Paris, Lavoisier, 1124 p.

CGDD (2012) Méthodes d'estimation de population et de logements en zone inondable (Rapport Développement durable). Paris, Ministère de l'Ecologie, du Développement Durable et de l'Energie.

Cutter, S., Boruff, B. \& Shirley, W. (2003) Social vulnerability to environmental hazards, Social Science Quarterly, 84, 242-261.

Cutter, S., Burton, C. \& Emrich, C. (2010) Disaster resilience indicators for benchmarking baseline conditions, Journal of Homeland Security and Emergency Management, 7,51-51.

Cutter, S., Ash, K. \& Emrich, C. (2014) The geographies of community disaster resilience, Global Environmental Change, 29, 65-77.

Dauphiné, A. \& Provitolo, D. (2013) Risques et catastrophes: observer, spatialiser, comprendre, gérer. Paris, Armand Collin, 416p.

De Moel, H., Jongman, B., Kreibich, H., Merz, B., Penning-Rowsell, E. \& Ward, P. (2015) Flood risk assessments at different spatial scales, Mitigation and Adaptation Strategies for Global Change, 20, 865-890.

DRIEE \& SGZDS-Paris (2015) Tableau récapitulatif des modélisations de zones inondables. Zones Inondées Potentielles. Paris. 
Eleuterio, J., Payraudeau, S. \& Rozan, A. (2008) Sensibilité de l'évaluation des dommages associés aux inondations en fonction de la caractérisation de la vulnérabilité des bâtiments, Ingénieries, $55-56,29-44$.

Elliott, J. (2010) Limits to social capital: comparing network assistance in two New Orleans neighborhoods devastated by hurricane Katrina, The Sociological Quarterly, 51, 624-648.

Enarson, E. \& Fordham, M. (2001) Line that divide, ties that bind: Race, class, and gender in women's flood recovery in the US and UK, The Australian Journal of Emergency Management, $15,43-53$.

Esnard, A.-M., Sapat, A. \& Mitsova, D. (2011) An index of relative displacement risk to hurricanes, Natural Hazards, 59, 833-859.

Etablissement Public Territorial de Bassin (EPTB) Seine Grands Lacs (2014) Programme d'actions de prévention des inondations de la Seine et de la Marne Franciliennes (PAPI). Synthèse, Paris, Hauts-de-Seine, Seine-Saint-Denis, Val de Marne, Mairie de Paris.

Falk, W., Hunt, M. \& Hunt, L. (2006) Hurricane Katrina and new Orleanians' sense of place, Du Bois Review, 3, 115-128.

Faytre, L. (2011) Urbanisation et zones inondables : les risques encourus (Note rapide - Territoires No. 557), Paris, Iau-Idf.

Fekete, A. (2009) Validation of a social vulnerability index in context to river-floods in Germany, Natural Hazards and Earth System Sciences, 9, 393-403.

Finch, C., Emrich, C. \& Cutter, S. (2010) Disaster disparities and differential recovery in New Orleans, Population and Environment, 31, 179-202.

Flanagan, B., Gregory, E., Hallisey, E., Heitgerd, J. \& Lewis, B. (2011) A social vulnerability index for disaster management, Journal of Homeland Security and Emergency Management, 8, 3-3.

Fothergill, A., Maestas, E. \& DeRouen Darlington, J. (1999) Race, Ethnicity and Disasters in the United States: a review of the literature, Disasters, 23, 156-173.

Fujiki, K., (2017) Etude prospective des impacts sociaux d'une inondation majeure en région Ile-deFrance. Disparités socio-spatiales dans la prise en charge des populations franciliennes en situation de crise et de post-crise: une analyse cartographiée et quantifiée des besoins des ménages, de l'évacuation à la reconstruction (PhD Thesis). Lyon, Université Jean Moulin Lyon 3.

Gilli, F. (2014) Grand Paris. L'émergence d'une métropole, Paris, Presses de Sciences Po.

Gotham, K. (2015) "Limitations, Legacies, and Lessons: Post-Katrina Rebuilding in Retrospect and Prospect”. American Behavioral Scientist, 59, 1314-1326.

Gotham, K. \& Greenberg, M. (2014) Crisis Cities. Disaster and Redevelopment in New York and New Orleans. Oxford University Press, Oxford.

Gralepois, M. (2008) Le Plan Communal de Sauvegarde. Une approche territoriale de la sécurité civile à travers l'enquête des conditions de mise en place dans les communes françaises (GT5 5ème Commission "Risques Industriels - Transports"), Paris, Conseil National de la Protection Civile.

Green, R., Bates, L. \& Smyth, A. (2007) Impediments to recovery in New Orleans' Upper and Lower Ninth Ward: one year after hurricane Katrina, Disasters, 31, 311-335.

Groen, J. \& Polivka, A. (2010) Going home after hurricane Katrina: determinants of return migration and changes in affected areas, Demography, 47, 821-844.

Hammond, M. (2014) Flood impact assessment literature review (Project Report - FP7 Collaborative research on flood resilience in urban areas). Exeter, European Community Seventh Framework Programme.

Hubert, G. \& Ledoux, B. (1999) Le coût du risque.... l'évaluation des impacts socio-économiques des inondations. Paris, Presses de l'Ecole Nationale des Ponts et Chaussées.

Hufschmidt, G. (2011) A comparative analysis of several vulnerability concepts, Natural Hazards, 58, 621-643.

IIBRBS (1998) Evaluation des dommages liés aux crues en région Ile-de-France, Paris, Hydratec, Société d'Ingénierie pour l'Eau et l'Environnement, Territoires Conseil. 
Kamel, N. (2012) Social Marginalisation, Federal Assistance and Repopulation Patterns in the New Orleans Metropolitan Area following Hurricane Katrina, Urban Studies, 49, 3211-3231.

Kamel, N. \& Loukaitou-Sideris, A. (2004) Residential assistance and recovery following the Northridge earthquake, Urban Studies, 41, 533-562.

Kates, R., Colten, C., Laska, S. \& Leatherman, S. (2006) Reconstruction of New Orleans after Hurricane Katrina: a research perspective, Proceedings of the National Academy of Science of the United States of America, 103, 14653-14660.

Koks, E., Jongman, B., Husby, T. \& Botzen, W. (2015) Combining hazard, exposure and social vulnerability to provide lessons for flood risk management, Environmental Science and Policy, $47,42-52$.

Le Masurier, J., Rotimi, J. \& Wilkinson, S. (2006) A comparison between routine construction and post-disaster reconstruction with case studies from New Zealand, in: 22nd ARCOM Conference on Current Advances in Construction Management Research, Association of Researchers in Construction management (ARCOM), Birmingham.

Lee, Y.-J. (2014) Social vulnerability indicators as a sustainable planning tool, Environmental Impact Assessment Review, 44, 31-42.

Leon, G. (2004) Overview of the psychosocial impact of disasters, Prehospital and Disaster Medicine, 19, 4-9.

Lindell, M. (2013) Recovery and reconstruction after disaster, in: Encyclopedia of Natural Hazards, Berlin, Springer et Business Media B.V., 812-824.

Logan, J. (2006), The impact of Katrina: race and class in storm-damaged neighborhoods, Providence, Brown University.

Masson-Planchon, S. \& Reghezza-Zitt, M. (2017) La planification au défi de l'incertitude. Faire face à l'inimaginable, in: La Gestion de crise à l'épreuve de l'exercice EU SEQUANA, Paris, La documentation française, 37-41, 145-148, 179-183.

Masozera, M., Bailey, M. \& Kerchner, C. (2007) Distribution of impacts of natural disasters across income groups: a case study of New Orleans, Ecological Economics, 63, 299-306.

Merz, B., Kreibich, H., Schwarze, R. \& Thieken, A. (2010) Review article "Assessment of economic flood damage", Natural Hazards and Earth System Sciences, 10, 1697-1724.

Moatty, A. \& Vinet, F. (2016) Post-disaster recovery: the challenge of anticipation, in: FLOODrisk 2016 - $3^{\text {rd }}$ European Conference on Flood Risk Management, Lyon.

Morrow-Jones, H. \& Morrow-Jones, C. (1991) Mobility Due to Natural Disaster: Theoretical Considerations and Preliminary Analyses, Disasters, 15, 126-132.

Myers, C., Slack, T. \& Singelmann, J. (2008) Social vulnerability and migration in the wake of disaster: the case of Hurricanes Katrina and Rita, Population and Environment, 29, 271-291.

November, V. \& Créton-Cazanave, L. (2017) La gestion de crise à l'épreuve de l'exercice EU SEQUANA, Paris, La documentation française.

OECD (2008) Handbook on constructing composite indicators. Methodology and user guide, Paris, OECD Publishing. Paris, 158p.

OECD (2014) Seine Basin, Ile-de-France, 2014: Resilience to major floods, OECD Publishing. Paris, $226 \mathrm{p}$.

Paxson, C. \& Rouse, C. (2008) Returning to New Orleans after hurricane Katrina, American Economic Review, 98, 38-42.

Peacock, W., Dash, N. \& Zhang, Y. (2007) Sheltering and Housing Recovery Following Disaster, in: Handbook of Disaster Research, New York, Springer New York, 258-274.

Rufat, S., Tate, E., Burton, C. \& Maroof, A.S. (2015) Social vulnerability to floods: review of case studies and implications for measurement, International Journal of Disaster Risk Reduction, 14, 470-486.

Rygel, L., O’Sullivan, D. \& Yarnal, B. (2006) A method for constructing a social vulnerability index: an application to hurricane storm surges in a developed country, Mitigation and Adaptation Strategies for Global Change, 11, 741-764. 
Salagnac, J.-L., Marchand, D., Florence, C., Delpech, P. \& Axès, J.-M. (2014) Impacts des inondations sur le cadre bâti et ses usagers (Rapport final). Champs-sur-Marne, Centre Scientifique et Technique du Bâtiment.

Sastry, N. (2009), Tracing the effects of hurricane Katrina on the population of New Orleans, Sociological Methods \& Research, 38, 171-196.

Shimada, G. (2015), The role of social capital after disasters: an empirical study of Japan based on Time-Series-Cross-Section (TSCS) data from 1981 to 2012, International Journal of Disaster Risk Reduction, 14, 388-394.

Smith, S. \& McCarty, C. (1996) Demographic effects of natural disasters: a case study of hurricane Andrew, Demography, 33, 265-275.

Su, S., Pi, J., Wan, C., Li, H., Xiao, R. \& Li, B. (2015) Categorizing social vulnerability patterns in Chinese coastal cities, Ocean \& Coastal Management, 116, 1-8.

Torterotot, J.-P. (1993) Le coût des dommages dus aux inondations: estimation et analyse des incertitudes (PhD Thesis). Paris, Ecole Nationale des Ponts et Chaussées.

Toubin, M. (2014) Améliorer la résilience urbaine par un diagnostic collaboratif. L'exemple des services urbains parisiens face à l'inondation (PhD Thesis). Paris, Université Paris-Diderot.

Tovar, E. \& Bourdeau-Lepage, L., (2013) Well-being Disparities within the Paris Region: A Capabilist Spatialised Outlook, Urban Studies, 50, 1575-1591.

Vigdor, J. (2008) The economic aftermath of hurricane Katrina, Journal of Economic, 22, 135-154.

Whittle, R., Medd, W., Deeming, H., Kashefi, E., Mort, M., Twigger Ross, C., Walker, G. \& Watson, N. (2010) After the rain - learning the lessons from flood recovery in Hull. Final Project Report (Flood, Vulnerability and Urban Resilience: a real-time study of local recovery following the floods of June 2007 in Hull). Lancaster, Lancaster University.

Wolf, T. \& McGregor, G. (2013) The development of a heat wave vulnerability index for London, United Kingdom, Weather and Climate Extremes, 1, 59-68.

Wright, K. \& Johnston, D. (2010) Post-earthquake sheltering needs; how loss of structures and services affects decision making for evacuation, in: New Zealand Society of Earthquake Engineering Conference, Wellington.

Xiao, Y. \& Van Zandt, S. (2011) Building community resiliency: spatial links between household and business post-disaster return, Urban Studies [Online] Available from: https://doi.org/10.1177/0042098011428178 [Accessed 9th March 2015].

Zhang, Y. (2006) Modeling single family housing recovery after hurricane Andrew in Miami-Dade County, FL (PhD Thesis). College Station, Texas A\&M University.

Zhang, Y. \& Peacock, W. (2009), Planning for housing recovery? Lessons learned from hurricane Andrew, Journal of the American Planning Association, 76, 5-24. 